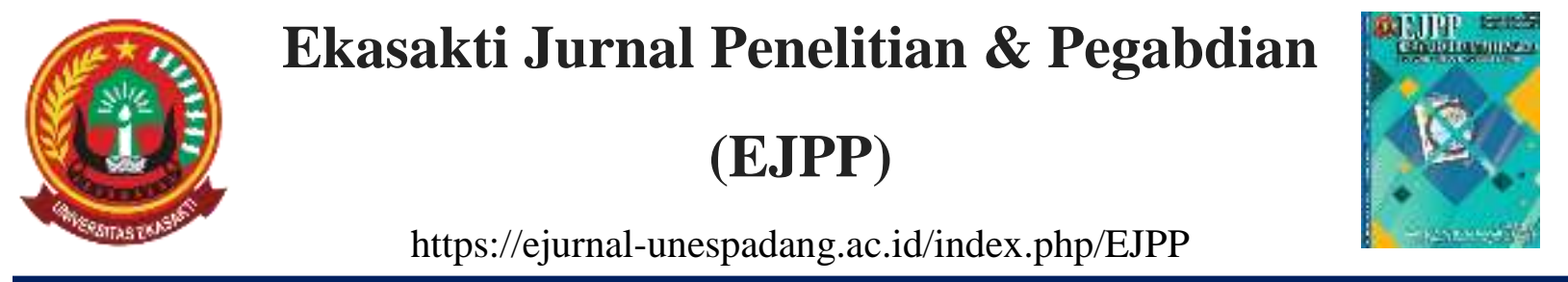

\title{
PENGARUH REALISASI BELANJA PEMBANGUNAN SARANA DAN PRASARANA DARI DANA DESA TERHADAP PENINGKATAN SATUAN PENDIDIKAN DI KABUPATEN PESISIR SELATAN
}

\author{
Irdham Riyanda $^{1}$, Foni Landasari ${ }^{2}$, dan Neng Kamarni ${ }^{3}$ \\ ${ }^{1)}$ Magister Ekonomi, Universitas Andalas, Padang \\ Email : irdhamriyanda@yahoo.com \\ ${ }^{2)}$ Magister Ekonomi Universitas Andalas, Padang \\ Email : foni.landa@yahoo.com \\ ${ }^{3)}$ Magister Ekonomi Universitas Andalas, Padang
}

\section{INFO ARTIKEL}

Received : 10/02/2021

Revised : 25/02/2021

Publish : 01/05/2021

Kata Kunci:

Dana Desa, Satuan

Pendidikan, Pesisir

Selatan.

\begin{abstract}
ABSTRAK
Penelitian ini bertujuan untuk menganalisis pengaruh realisasi belanja pembangunan sarana dan prasarana pendidikan dari Dana Desa terhadap peningkatan satuan pendidikan swasta di Kabupaten Pesisir Selatan. Penelitian ini menggunakan pendekatan statistic deskriptif. Pengambilan data dilakukan dengan pengumpulan data sekunder dari data Potensi Desa (PODES) BPS dan nilai realisasi belanja diperoleh dari Pemerintah Kabupaten Pesisir Selatan. Data yang diperoleh akan diolah dengan menggunakan metode regresi linier sederhana. Hasil analisis menunjukkan bahwa realisasi belanja pembangunan sarana dan prasarana pendidikan dari DD berpengaruh positif dan signifikan terhadap peningkatan jumlah satuan pendidikan swasta di Kabupaten Pesisir Selatan.
\end{abstract}

Keywords:

Village Fund, Education

Unit, Pesisir Selatan.

\begin{abstract}
This study aims to analyze the effect of the realization of spending on the development of educational facilities and infrastructure from the Village Fund on the increase in private education units in Pesisir Selatan Regency. This study uses a descriptive statistical approach. Data collection was carried out by collecting secondary data from the Village Potential data (PODES) of BPS and the actual value of expenditure obtained from the Pesisir Selatan Regency Government. The data obtained will be processed using a simple linear regression method. The results of the analysis show that the realization of spending on the development of educational facilities and infrastructure from $D D$ has a positive and significant effect on the increase in the number of private education units in Pesisir Selatan Regency.
\end{abstract}

DOI: $\underline{\text { https://doi.org/10.31933/ejpp.v1i2.315 }}$ 


\section{PENDAHULUAN}

Salah satu agenda pembangunan nasional (Nawacita) Tahun 2015-2019 yaitu membangun Indonesia dari pinggiran dengan memperkuat daerah-daerah dan desa dalam kerangka negara kesatuan. Amanat pada Undang-Undang Nomor 6 tahun 2014 tentang Desa (UU Desa) diatur adanya sumber pembiayaan kepada desa berupa Dana Desa (DD). Salah satu prioritas penggunaan DD berdasarkan pasal 19 ayat (2) Peraturan Pemerintah Nomor 60 tahun 2014 tentang Dana Desa yang Bersumber dari APBN ((PP DD) adalah membiayai pembangunan pelayanan dasar pendidikan.

Secara nasional, proporsi dana transfer baik berupa DD maupun Alokasi Dana Desa (ADD) masih dominan dibandingkan sumber penerimaan lainnya. Hal tersebut terlihat dari data BPS bahwa dalam lingkup nasional, pada 2019, struktur pendapatan desa masih didominasi komponen DD sebesar 58,25\% dari pendapatan desa dan komponen ADD sebesar 30,42\%. Hal yang sama juga terjadi pada tingkat Nagari di wilayah Provinsi Sumatera Barat, bahwa berdasarkan data BPS pada Pronvisi Sumatera Barat struktur dominan pembentuk pendapatan bersumber dari DD sebesar 49,55\% dan ADD sebesar 47,22\%. Adapun pada salah satu daerah yang akan dijadikan objek dalam penelitian ini yaitu Kabupaten Pesisir Selatan (Pessel) diketahui pada tahun 2019, sebesar 64,26\% sumber pendapatan bersumber dari DD, dan sebesar $33,18 \%$ bersumber dari Alokasi Dana Desa (ADD).

Namun atas alokasi DD yang besar tersebut, belum dapat mendorong peningkatan tingkat pendidikan di Kabupaten Pesisir Selatan. Berdasarkan dokumen Rencana Strategis (Renstra) Pemerintah Kabupaten Pesisir Selatan Tahun 2016-2021, salah satu analisa kelemahan daerah adalah belum meratanya akses masyarakat terhadap layanan pendidikan yang bermutu terutama bagi masyarakat nagari yang relatif tertinggal, termasuk dikarenakan kurangnya sarana dan prasarana pendidikan.

Permasalahan yang menarik untuk diteliti adalah pada pengaruh DD terhadap peningkatan jumlah satuan pendidikan di tiap-tiap desa/nagari. Peningkatan pada jumlah sekolah negeri tidak relevan untuk dijadikan variable dikarenakan pembangunan dan pengelolaan sekolah negeri merupakan kewenangan pemerintah daerah, dan bukan bersumber dari DD. Adapun berdasarkan laporan BPS pada tahun 2020 Kabupaten Pesisir Selatan mempunyai jumlah Taman Kanak Kanak (TK) swasta sebanyak 141, Sekolah Dasar (SD) swasta sebanyak 14, Madrasah Ibtidaiyah Swasta sebanyak 10, SMP swasta sebanyak 3, Madrasah Tsnawiyah (MTs) swasta sebanyak 19, SMA swasta sebanyak 0, SMK swasta sebanyak 8, Madrasah Aliyah (MA) swasta sebanyak 13 (Statistik, Kabupaten Pesisir Selatan Dalam Angka 2020, 2020).

Salah satu syarat terwujudnya pendidikan yang baik adalah keberadaan jenjang satuan pendidikan mulai dari tingkat dasar, menegah dan tinggi. Hal tersebut sejalan dengan pendapat Carter V. Good dalam Irawansyah yang menyatakan bahwa pendidikan adalah proses perkembangan kecakapan individu dalam sikap dan perilaku bermasyarakat melalui proses sosial dimana seseorang dipengaruhi oleh suatu lingkungan yang terorganisir, seperti rumah atau sekolah, sehingga dapat mencapai perkembangan diri dan kecakapan sosial (Irawansyah, 2016). 
Sejalan dengan hal tersebut, Undang-Undang Sistem Pendidikan Nasional (UU Sisdiknas) pada Pasal 16 mengatur bahwa penyelenggaraan pendidikan dapat dilakukan baik oleh pemerintah, pemerintah daerah maupun masyarakat (swasta). Menurut Redja Mudyahardjo, secara simplistik pendidikan dapat diinterprestasikan erat kaitannya dengan sekolah atau satuan pendidikan, yaitu proses belajar-mengajar yang diselenggarakan disekolah sebagai suatu jenjang pendidikan formal (Mudyahardjo, 2008).

Selanjutnya, berdasarkan PP DD pada pasal 19 diatur bahwa peruntukan DD diprioritaskan untuk membiayai pembangunan desa dan kemasyarakatan. Adapun pada bagian penjelasan diatur bahwa lingkup pembangunan tersebut adalah seperti pembangunan pelayanan dasar pendidikan, kesehatan dan infrastruktur. Berdasarkan laporan dari Dinas Pemberdayaan Masyarakat Desa dan PPKB Kabupaten Pessel diketahui presentase belanja Bidang Pembangunan Desa yang dialokasikan untuk pembangunan satuan pendidikan pada 2018 adalah sebesar Rp8.263.146.959,00 dari total realisasi belanja pembangunan desa sebesar Rp234.532.843.000,00 (3,52\%), dan pada tahun 2019 mengalami penurunan yaitu sebesar Rp6.267.727.966,00 dari total realisasi belanja pembangunan desa sebesar Rp264.428.184.000,00 (2,37\%).

Penelitian ini hanya akan mengidentifikasi pengaruh DD untuk realisasi pembangunan satuan pendidikan terhadap peningkatan pembangunan satuan pendidikan swasta.

\section{METODE PENELITIAN}

Jenis penelitian ini adalah penelitian deskriptif-statistik, metode yang dipergunakan dalam penelitian adalah metode kuantitatif dengan menggunakan data sekunder melalui database Potensi Desa (Podes) tahun 2018 dan 2019. Lokasi penelitian adalah pada Nagari di lingkungan Kabupaten Pessel dan periode data penelitian adalah tahun 2018 dan 2019.

Populasi dalam penelitian adalah seluruh Nagari di Kabupaten Pessel sebanyak 77 Nagari yang mempunyai realisasi belanja pembangunan sarana dan prasarana pendidikan pada tahun 2018 atau 2019. Penetapan sample diambil dengan menggunakan metode purposive sampling dengan kriteria data yang diolah adalah data realisasi anggaran yang dikeluarkan sebatas pada tahun 2018 dan 2019 sebanyak 27 Nagari. Variabel yang dipergunakan dalam penelitian ini adalah variable realisasi belanja (Y) dan peningkatan satuan pendidikan (X). Metode analisa data yang dipergunakan adalah regresi linier sederhana menggunakan aplikasi SPSS versi 21, dengan definisi operasional variable sebagai berikut:

Tabel 1. Defisini operasional Variabel

\begin{tabular}{lcl}
\hline \multicolumn{1}{c}{ Variabel Terikat } & Variabel Bebas & \multicolumn{1}{c}{ Definisi Operasional Variable } \\
\hline $\begin{array}{l}\text { Peningkatan jumlah satuan Pendidikan swasta dari } \\
\text { tahun 2018 }-2019(\mathrm{Y})\end{array}$ & $\mathrm{X}$ & $\begin{array}{l}\text { Realisasi Dana Desa Bidang } \\
\text { Pembangunan Pendidikan }\end{array}$ \\
\hline
\end{tabular}

Spesifikasi model empiris analisis regresi diperoleh: $Y=\alpha+\beta X+\mu(1)$ 


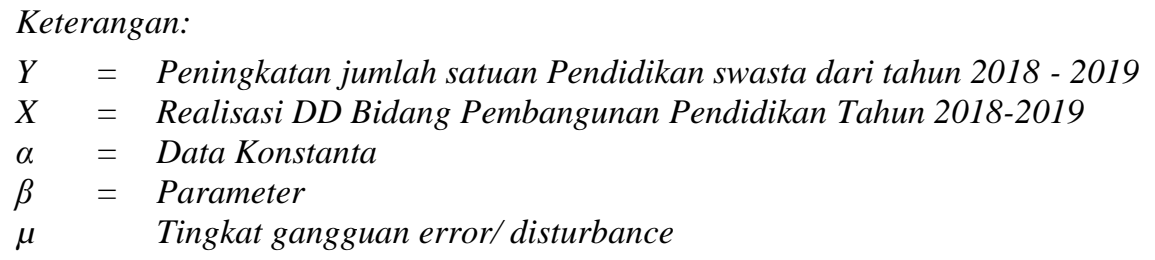

\section{HASIL DAN PEMBAHASAN}

\section{Hasil Uji Normalitas}

Berikut hasil Uji Normalitas yang telah diolah dengan menggunakan SPSS versi 21:

Tabel 2. One-Sample Kolmogorov-Smirnov Test

\begin{tabular}{lrrrr}
\hline & & ALOKASI BELANJA & PODES & Unstandardized Residual \\
\hline$N$ & & 27 & 27 & 27 \\
Normal & Mean & 232417900,19 & $-28,26$ & 0,0000000 \\
Parameters ${ }^{a, b}$ & Std. Deviation & 197035732,580 & 72,027 & 66,04550482 \\
& Absolute & 0,189 & 0,273 & 0,140 \\
Most Extreme & Positive & 0,189 & 0,273 & 0,122 \\
Differences & Negative & $-0,155$ & $-0,160$ & $-0,140$ \\
Kolmogorov-Smirnov $Z$ & 0,984 & 1,420 & 0,727 \\
Asymp. Sig. (2-tailed) & 0,288 & 0,035 & 0,666 \\
\hline
\end{tabular}

Sumber: Data diolah dengan SPSS v.21 (2021)

Berdasarkan table 2 diatas, hasil signifikansi dengan pendekatan uji one sample kolmogorov smirnov sebesar 0,666, sehingga data dapat dinyatakan normal. Karena nilai signifikansi lebih besar dari 0,05 yaitu $(0,666>0,05)$.

\section{Uji Lineatitas}

Berikut hasil Uji Linearitas yang telah diolah dengan menggunakan SPSS versi 21:

Tabel 3. Hasil Uji Linearitas

\begin{tabular}{ccc}
\hline Variabel & Signifikan & Keterangan \\
\hline PODES*ALOKASI BELANJA & 0,390 & Linear \\
\hline
\end{tabular}

Sumber: Data diolah dengan SPSS v.21 (2021)

Berdasarkan tabel 3 diatas dapat dilihat bahwa nilai Deviation from linearity Sig. adalah 0,390 lebih besar dari 0,05. Maka dapat diartikan bahwa ada hubungan linear secara signifikan antara variabel Alokasi Belanja dengan variabel PODES (Peningkatan Jumlah Satuan Pendidikan Swasta). 


\section{Uji r dan $\mathbf{r}^{2}$}

Berikut hasil Uji $r$ dan $\mathrm{r}^{2}$ yang telah diolah dengan menggunakan SPSS versi 21:

Tabel 4. Hasil Uji R dan $\mathbf{R}^{2}$

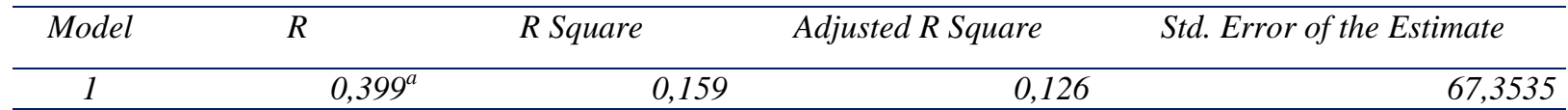

Sumber: Data diolah dengan SPSS v.21 (2021)

Berdasarkan tabel diatas, nilai r yang merupakan simbol dari nilai koefisien korelasi sebesar 0,399. Nilai ini dapat diinterpretasikan bahwa hubungan kedua variabel penelitian ada di kategori lemah. Melalui tabel ini juga diperoleh nilai $r^{2}$ yang menunjukan seberapa bagus model regresi yang dibentuk oleh interaksi variabel bebas dan terikat yaitu sebesar 15,9\% yang artinya ALOKASI BELANJA memiliki pengaruh kontribusi sebesar 15,9\% terhadap PODES (Peningkatan Jumlah Satuan Pendidikan Swasta) dan 84,1\% lainnya dipengaruhi oleh faktorfaktor lain diluar variabel alokasi belanja.

\section{Analisis Regresi Linear Sederhana}

Berikut hasil Analisis regresi linear sederhana yang telah diolah dengan menggunakan SPSS versi 21:

Tabel 5. Hasil Uji Analisis Regresi Linear Sederhana

\begin{tabular}{|c|c|c|c|c|c|c|}
\hline & \multirow{2}{*}{ Model } & \multicolumn{2}{|c|}{ Unstandardized Coefficients } & \multirow{2}{*}{$\frac{\text { Standardized Coefficients }}{\text { Beta }}$} & \multirow{2}{*}{$t$} & \multirow{2}{*}{ Sig. } \\
\hline & & $B$ & Std. Error & & & \\
\hline \multirow{2}{*}{1} & (Constant) & $-62,158$ & 20,268 & & $-3,067$ & 0,005 \\
\hline & Alokasi Belanja & $1,459 E-007$ & 0,000 & 0,399 & 2,176 & 0,039 \\
\hline
\end{tabular}

Sumber: Data diolah dengan SPSS v.21 (2021)

Berdasarkan tabel diatas, dapat diketahui hasil analisis regresi linear sederhana. Maka dapat diperoleh persamaan regresi sebagai berikut: PODES $=-62,158+0,0001459$ ALOKASI BELANJA.

Persamaan regresi diatas memiliki makna:

1. Konstanta sebesar $-62,158$ menyatakan bahwa jika ALOKASI BELANJA memiliki angka 0, maka PODES (Peningkatan Jumlah Satuan Pendidikan Swasta) adalah sebesar $-62,158$.

2. ALOKASI BELANJA memiliki koefisien regresi dengan arah positif sebesar 0,0001459. Hal ini menunjukan bahwa apabila terjadi kenaikan sebesar Rp1.000.000 pada ALOKASI BELANJA, maka PODES (Peningkatan Jumlah Satuan Pendidikan Swasta) akan naik sebesar 0,0001459. 


\section{Uji t}

Hasil uji t dapat dilihat pada tabel 6 dibawah ini:

Tabel 6. Hasil Uji t

\begin{tabular}{lcc}
\hline \multicolumn{1}{c}{ Model } & $t$ & Sig \\
\hline (Constant) & $-3,067$ & 0,005 \\
ALOKASI BELANJA & 2,176 & 0,039
\end{tabular}

Sumber: Data diolah dengan SPSS v.21 (2021)

Berdasarkan pengujian hipotesis yang telah dilakukan pada tabel 6 maka dapat diketahui Alokasi Belanja memikili t hitung sebesar 2,176 dengan nilai signifikan 0,039 sedangkan untuk t tabel dapat dicari dengan menggunakan derajat kebebasan n-k-1. Dimana $n$ adalah jumlah sampel, sedangkan $\mathrm{k}$ adalah jumlah variabel independen. Maka, 27-1-1 = 25 serta menggunakan tingkat keyakinan 5\% $(\alpha=0,05)$ sehingga t tabel sebesar 2,059. Karena t hitung 2,176 > t tabel 2,059 dan tingkat signifikan 0,039<0,05. Hal ini menunjukkan Alokasi Biaya berpengaruh positif dan signifikan terhadap PODES (Peningkatan Jumlah Satuan Pendidikan Swasta).

Berdasarkan hasil pengujian regresi linier sederhana diperoleh koefisien regresi bernilai positif, dan dari hasil uji signifikansi diperoleh bahwa realisasi DD untuk pembangunan sarana dan prasarana pendidikan berpengaruh signifikan terhadap peningkatan satuan pendidikan, meskipun pengaruhnya relatif kecil. Hal tersebut sejalan dengan hasil penelitian Paxson dan Schady (2002), Akbar dan Sihaolo (2019), Rahayu (2017), serta amanat PP DD pada pasal 19.

\section{KESIMPULAN}

\section{Simpulan}

Berdasarkan hasil analisa diketahui hal-hal berikut:

1. Pengaruh antara nilai realisasi belanja DD Bidang Pembangunan Desa pada jenis Pembangunan Sarana dan Prasarana Pendidikan dengan peningkatan jumlah satuan pendidikan swasta, dapat diperoleh melalui uji regresi linier sederhana;

2. Hasil perhitungan uji linearitas menyatakan bahwa terdapat hubungan linier secara signifikan antara variable realisasi belanja DD tahun 2018-2019 dengan peningkatan satuan pendidikan pada 2018-2019 sebesar 0,39;

3. Uji $\mathrm{R}$ dan $\mathrm{R}^{2}$ membuktikan bahwa hubungan kedua variable ada di kategori lemah, sedangkan uji $\mathrm{r}^{2}$ menghasilkan nilai $15,9 \%$ terhadap peningkatan jumlah satuan pendidikan swasta sehingga $84,1 \%$ lain peningkatan satuan pendidikan ditentukan oleh factor lain diluar pengaruh DD Bidang Pembangunan Desa; 
4. Analisa regresi linier sederhana menunjukan bahwa apabila terjadi kenaikan sebesar Rp1.000.000,00, maka variable peningkatan jumlah satuan pendidikan swasta akan naik sebesar 0,0001459;

5. Hasil uji t menunjukan bahwa nilai t hitung > t table dan tingkat signifikansi 0,039< 0,05, maka menunjukan realisasi belanja DD Pembangunan Sarana Prasarana Pendidikan berpengaruh positif dan signifikan terhadap peningkatan jumlah satuan pendidikan swasta;

\section{Saran}

Nilai uji $\mathrm{r}^{2}$ yang hanya menghasilkan $15,9 \%$ terhadap peningkatan jumlah satuan pendidikan swasta dan terdapat $84,1 \%$ peningkatan satuan pendidikan dipengaruhi faktor lain merupakan saran kami untuk dilakukan penelitian lebih lanjut dalam penelitian berikutnya. Hasil kajian dari Katalin Kovács atas tingginya peran modal sosial dan budaya dalam eksistensi satuan pendidikan dapat menjadi bahan kajian awal.

\section{REFERENSI}

Akbar Thoriq Mochamad, \& Sihaloho Dariatno Estro. (2019). The Impact of Village Fund Program in Developing Physical Infrastructure: Case. Media Trend Volume 14 Nomor 2, 194-200.

Badan Pusat Statistik. (2015-2019). Statistik Keuangan Pemerintah Desa Tahun 2016-2019. Jakarta: Badan Pusat Statistik.

BPS. (2020). Provinsi Sumatera Barat Dalam Angka. Padang: BPS.

DesaUndang Nomor 6 tahun 2014 tentangUndang. (2014). Undang Undang Nomor 6 tahun 2014 tentang Desa. Jakarta: Indonesia.

Irawansyah. (2016). Kepemimpinan dalam Perspektif Manajemen Pendidikan. Al-Idarah : Jurnal Kependidikan Islam Volume 6 Nomor 2 , 197-216.

Kovács Katalin. (2012). Rescuing a small village school in the context of rural change in Hungary. Journal of Rural Studies Vol 28, 108-117.

Mudyahardjo Redja. (2008). Pengantar Pendidikan Sebuah Studi Awal Tentang Dasar-dasar Pendidikan pada Umumnya dan Pendidikan di Indonesia. MudyahardjoRedja, Pengantar Pendidikan Sebuah Studi Awal Tentang Dasar-dasar Pendidikan pada Umumnya dan Pendidikan di Indonesia. Jakarta: Raja Grafindo Persada.

Paxson Christina, \& SchadyRNorbert. (2002). The Allocation and Impact of Social Funds: Spending on School Infrastructure in Peru. The World Bank Economic Review Volume 16 Nomor 2, 297-319.

PP DesaPemerintah Pelaksana UUPeraturan. (2014). Peraturan Pelaksana UU No 6 tahun 2014 tentang Desa. Jakarta: Indonesia. 
Rahayu Depi. (2017). Strategi Pengelolaan Dana Desa untuk Meningkatkan Kesejahteraan Masyarakat Desa Kalikayen Kabupaten Semarang. Economics Development Analysis Journal Vol 6 Nomor 2, 107-116. 